\title{
Reporting Key Features in Cold-Adapted Bacteria
}

\author{
Paula M. Tribelli ${ }^{1,2}$ and Nancy I. López ${ }^{1,2, * \text { (D) }}$ \\ 1 Departamento de Química Biológica, Facultad de Ciencias Exactas y Naturales, Universidad de Buenos \\ Aires, C1428EGA Buenos Aires, Argentina; paulatrib@qb.fcen.uba.ar \\ 2 IQUIBICEN, CONICET, C1428EGA Buenos Aires, Argentina \\ * Correspondence: nan@qb.fcen.uba.ar; Tel.: +54-11-4576-3334
}

Received: 30 January 2018; Accepted: 12 March 2018; Published: 13 March 2018

\begin{abstract}
It is well known that cold environments are predominant over the Earth and there are a great number of reports analyzing bacterial adaptations to cold. Most of these works are focused on characteristics traditionally involved in cold adaptation, such as the structural adjustment of enzymes, maintenance of membrane fluidity, expression of cold shock proteins and presence of compatible solutes. Recent works based mainly on novel "omic" technologies have presented evidence of the presence of other important features to thrive in cold. In this work, we analyze cold-adapted bacteria, looking for strategies involving novel features, and/or activation of non-classical metabolisms for a cold lifestyle. Metabolic traits related to energy generation, compounds and mechanisms involved in stress resistance and cold adaptation, as well as characteristics of the cell envelope, are analyzed in heterotrophic cold-adapted bacteria. In addition, metagenomic, metatranscriptomic and metaproteomic data are used to detect key functions in bacterial communities inhabiting cold environments.
\end{abstract}

Keywords: psychrophile; energy generation; polyhydroxyalkanoates; cell envelopes; cold-adapted bacterial communities

\section{Introduction}

Temperature is a key factor for bacterial survival. Cold environments are predominant over the Earth. A great amount of information was generated analyzing bacterial adaptations to cold (e.g., [1-6]). Traditional characteristics involved in cold adaptation entail structural adjustment of enzymes, maintenance of membrane fluidity, expression of cold shock proteins, adaptation of the translation and transcription machinery and the presence of compatible solutes [3].

Microorganisms inhabiting cold environments are denominated psychrophiles, a term defined by Morita [7] and proposed for microorganisms that have optimum growth temperatures lower than $15{ }^{\circ} \mathrm{C}$ with upper temperatures around $20^{\circ} \mathrm{C}$. From an ecological point of view, the names 'eurypsychrophile' and 'stenopsychrophile' were used to reflect wide and narrow tolerance to temperature, respectively [8]. Since growth rate is not the best indicator of physiological state under low temperatures [6,9], the degree of adaptation to cold should be considered for psychrophile definition. Different nomenclature can be used to describe different aspects related to life in cold conditions, however the term cold-adapted bacteria will be used in this work focused on bacteria indigenous to cold environments.

The aim of this review was to analyze different strategies of cold-adapted bacteria, looking for novel features and/or activation of non-classical metabolisms for a cold lifestyle. We propose that, superimposed on generalized characteristics-almost universally present in cold-adapted bacteria-there are other specific features of each taxonomic group that are relevant and contribute to the adjustment of the whole cold adaptation landscape. For this purpose, the contribution of 
metagenomic and metaproteomic data was analyzed to detect key functions in bacterial communities that inhabit cold environments.

\section{Metabolic Features Related to Energy Generation in Cold Environments}

Novel 'multi-omic' approaches allow the acquisition of information related to the functionality of genotypic traits. Most of these works involving transcriptomic and proteomic analysis have highlighted the modifications of metabolic pathways that take place under cold conditions. As a general conclusion from this amount of information, it is known that many studied bacteria downregulate primary metabolism under cold conditions (Table 1).

Table 1. Cold adaptive bacterial responses revealed by genomic, transcriptomic and proteomic studies.

\begin{tabular}{|c|c|c|c|c|c|}
\hline \multirow[b]{2}{*}{ Bacterial Species } & \multicolumn{3}{|c|}{ Metabolic Features } & \multirow[b]{2}{*}{$\begin{array}{l}\text { Increase of } \\
\text { Membrane } \\
\text { Fluidity }\end{array}$} & \multirow[b]{2}{*}{ References } \\
\hline & $\begin{array}{c}\text { TCA } \\
\text { Repression or } \\
\text { Shortened }\end{array}$ & $\begin{array}{l}\text { Cytochrome } \\
\text { Repression }\end{array}$ & $\begin{array}{c}\text { Presence of } \\
\text { Alternative } \\
\text { Pathways }\end{array}$ & & \\
\hline Exiguobacterium sibiricum & NI & $X$ & $x^{a}$ & $X$ & [10] \\
\hline Nesterenkonia sp. AN1 & NI & NI & $x^{a}$ & $x$ & [11] \\
\hline Planococcus halocryophilus Or1 & $X$ & $x$ & $x^{a}$ & Decrease & [12-14] \\
\hline Pseudoalteromonas haloplanktis & $X$ & $X$ & NI & $x$ & {$[15]$} \\
\hline Pseudomonas extremaustralis & $x$ & $X$ & $X^{c}$ & NI & [16] \\
\hline Psychrobacter arcticus 273-4 & $X$ & NI & $X^{a}$ & $x$ & [17] \\
\hline Sphingopyxis alaskensis & $x$ & $x$ & $x^{b}$ & $x$ & [18] \\
\hline
\end{tabular}

X: presence of the feature; NI: not informed; ${ }^{a}$ : Glyoxylate and methyglyoxal pathways; ${ }^{\text {b: }}$ Propionyl-CoA catabolism;

c: Ethanol oxidation; TCA: tricarboxylic acid cycle.

Oxygen solubility increases at low temperatures, generating the increase of reactive oxygen species (ROS), which leads to oxidative stress. For this reason, oxidative metabolism such as glycolysis, the pentose phosphate pathway, the tricarboxylic acid cycle (TCA) and the electron transport chain are generally depressed at low temperatures [19]. Although this adjustment of ROS-producing pathways is recognized, the underlying molecular mechanisms and the alternative metabolic pathways involved in bacterial cold-adaptation are still not fully understood. In this section, several selected examples of heterotrophic bacteria isolated from different cold environments are analyzed, trying to find support for the statement that cold-adapted bacteria can use shortened or non-central metabolic pathways to thrive in the cold.

Reconstruction of carbon metabolism in Psychrobacter arcticus 273-4, a Siberian permafrost bacterium able to grow at $-10^{\circ} \mathrm{C}$, showed that it lacks glycolysis genes and a phosphotransferase system but possesses gluconeogenic enzymes, fructose-1,6-bisphosphatase and phosphoenolpyruvate synthase, suggesting that although it is not able to utilize sugars, other oxidized carbon sources are preferred [17]. Phenotypic analysis indicated that the energy metabolism of this bacterium is based on acetate, a compound found in that environment that can easily diffuse into the cell without cost-associated transport systems. A recent study of transcriptomic and proteomic responses to low temperatures in Psychrobacter sp. PAMC 21119, isolated from Antarctic permafrost soil, also showed that pathways for acetyl-CoA metabolism were upregulated while proteins involved in energy production and conversion were downregulated [20]. The utilization of glyoxylate shunt can provide intermediate carbon compounds to fulfill biosynthetic requirements [17]. The induction of genes encoding enzymes involved in the glyoxylate cycle at $5{ }^{\circ} \mathrm{C}$ was also observed in Nesterenkonia sp. AN1, a member of Actinobacteria isolated from Antarctic soil [11]. In another bacterium isolated from permafrost-Exiguobacterium sibiricum - the presence of methylglyoxal synthase was proposed by Rodriguez et al. [10] as an important feature for bypassing the lower part of glycolysis, since it is an alternative catabolic pathway for triose phosphates. Glyoxalase family proteins have also been recognized as key components in Planococcus halocryophilus Or1, a non-spore forming Firmicutes isolated from subzero temperatures from high Arctic permafrost [12]. The breakdown of glyoxal and 
methylglyoxal, formed as by-products of several metabolic pathways under subzero conditions, allows the removal of reactive electrophilic species through the recycling of reactive carbonyls to lactate, which is further used for cellular metabolism [12]. These results were in line with previous work, showing that, in this bacterium, energy metabolism was repressed at $-15^{\circ} \mathrm{C}$. However, the expression of succinic semialdehyde dehydrogenase, alcohol dehydrogenase and several oxidoreductases are increased, a fact that was attributed to the maintenance of energy metabolism and ATP levels [13]. A similar finding was reported in a transcriptomic analysis of Pseudomonas extremaustralis, a bacterium isolated from a temporary pond in Antarctica, in which the genes involved in primary metabolism were downregulated while those involved in ethanol oxidation-exaA, exaB and exaC-encoding a pyrroloquinoline quinone (PQQ)-dependent ethanol dehydrogenase, cytochrome c550 and an aldehyde dehydrogenase respectively, were upregulated [16]. Surprisingly, genetic and physiological approaches showed that this secondary pathway was essential for growth under low temperatures, as mutant strains in different ethanol oxidation related genes were unable to grow under cold conditions [16]. This result shows that, despite the lower energy yield in comparison with central metabolism, ethanol oxidation becomes essential under cold conditions where TCA and cytochrome coding genes are repressed [16].

In the marine bacterium Sphingopyxis alaskensis, which inhabits permanently cold waters $\left(4-10^{\circ} \mathrm{C}\right)$, the fatty acid metabolism influences energy generation since five enzymes of the fatty acid degradation pathway ( $\beta$-oxidation) were more abundant at low temperatures, rendering acetyl-CoA, which can enter to the TCA [18]. These authors also observed that fatty acid enzymes have a role in the propionate pathway, where propionyl-CoA is the central metabolic intermediate. Propionyl-CoA can also be obtained from the catabolism of some aminoacids, and can be carboxylated to S-methylmalonyl-CoA and subsequently isomerized to succinyl-CoA, another intermediate of TCA [18]. Similarly, RNAseq studies of the well-characterized model strain Pseudomonas putida KT2440, growing at $10^{\circ} \mathrm{C}$, showed that the 2-methylcitrate pathway and branched aminoacid degradation were upregulated [21], allowing catabolization of propionate and propionyl-CoA, which are further transformed into 2-methylcitrate and later processed to succinate and pyruvate [22,23]. P. putida KT2440 is a derivative strain of the soil isolate P. putida mt-2 [24], which can grow at low temperatures $[21,25,26]$. Although this bacterium is not indigenous to cold environments, it shows similar adaptations, obtaining intermediate compounds for TCA replenishment by alternative pathways. This evidences the extent of this strategy for cold adaptation.

Overall, during cold growth, the glycolysis and TCA cycle seems to be repressed while other secondary pathways or the obtainment of intermediate compounds by alternative routes to bypass the complete pathway arise as important features for energy generation.

\section{Compounds and Mechanisms Involved in Stress Resistance and Cold Adaptation}

\subsection{Compatible Solutes and Related Compounds}

The importance of traits related to the metabolism of compatible solutes to cope with cold has been recognized in many cold-adapted bacteria. These compounds play an important role in osmoprotection and cryoprotection but can also function as carbon, nitrogen and energy sources [27]. The main studied compounds, glycine, betaine, glycerol, trehalose, sucrose, mannitol and sorbitol, can reduce the freezing point of the cytoplasm, prevent macromolecule aggregation, scavenge free radicals and stabilize cellular membranes under cold conditions [28].

Recently, genome comparison and global phenotypic characterization of two Antarctic strains of Pseudoalteromonas, P. haloplanktis TAC125 and Pseudoalteromonas sp. TB41, conducted at $4{ }^{\circ} \mathrm{C}$ and $15^{\circ} \mathrm{C}$ revealed differences for cold adaptation. Remarkably, protein S-thiolation, regulated by glutathione and glutathionylspermidine, appeared to be a new possible mechanism for cold adaptation in TAC125 [29]. The study provided evidence of the relevance of glutathione metabolism in this bacterium that showed enhanced uptake (or catabolism) of compounds that may confer cryotolerance such as spermine, 
glutathione and ornithine [29]. These compounds probably link compatible solutes and oxidative stress resistance. In line with these findings, genome analysis of Colwellia psychrerythraea showed the presence of genes coding for proteins involved in the synthesis and the degradation of polyamides, nitrogen reserves polymers, considered as a probable unique adaptation to cold environments $[27,30]$. Moreover, metabolomic analysis of the Arctic isolate Mesorhizobium sp. Strain N33 revealed an increment in the accumulation of sarcosine, threonine and valine when this bacterium was grown at $4{ }^{\circ} \mathrm{C}$, probably acting as cryoprotectants [31].

\subsection{Polyhydroxyalkanoates Metabolism}

Several bacteria indigenous to cold environments can synthesize polyhydroxyalkanoates (PHAs)—reserve polymers that have an important physiological role. These polymers are accumulated under unbalanced growth conditions, such as an excess of carbon source with respect to other nutrients such as nitrogen or phosphorus, acting as dynamic reservoirs of carbon and reducing equivalents [32]. PHAs endow bacteria with enhanced survival and resistance to a variety of environmental stress conditions while also having ecological relevance (e.g., [33-36]). Genome analysis of $C$. psychrerythraea revealed the capacity to produce PHA linked with its significant ability to produce and degrade fatty acids. Multiple gene duplications of acyl-CoA dehydrogenase and enoyl-CoA hydratase gene families were detected, probably indicating versatility in PHAs characteristics that it can synthesize [27]. Later proteomic analysis showed a significant increase in PHA depolymerase after $24 \mathrm{~h}$ at $-10{ }^{\circ} \mathrm{C}$, suggesting polymer utilization under freezing conditions [30].

In S. alaskensis, proteome analysis revealed an increased abundance of enzymes related to PHA synthesis at low temperatures, probably indicating that it may compensate for reduced rates of enzyme activity and nutrient transport, as an adaptive strategy to ensure that this pathway remains functional in the cold [18]. Among the proteins involved in PHA biosynthesis, phasins are the major PHA granule-associated protein that has multiple functions, and it has been proposed that it could play an active role in stress protection and fitness enhancement [37]. The PhaP phasin of S. alaskensis, along with a 3-hydroxybutyrate dehydrogenase that is presumably secreted, were found increased at low temperatures [18]. These findings suggested that the contribution of PHA metabolism to cold adaptation in S. alaskensis involves both the synthesis of PHA de novo and the secretion of enzymes suitable for scavenging extracellular PHA [18].

P. extremaustralis shows important traits related to the role of PHAs for low temperature adaptability. This bacterium produces a different kind of PHAs, short chain length PHAs (sclPHAs) as polyhydroxybutyrate (PHB) and medium chain length PHAs (mclPHAs) [38]. In particular, PHB production was found to be fundamental for cold growth and freezing survival [39]. PHB accumulation increased motility and the survival of planktonic cells in the biofilms developed by this bacterium under cold conditions, suggesting that the capability to accumulate PHB could constitute an adaptive advantage for the colonization of new ecological niches in those environments [40]. Interestingly, PHB production is not a common characteristic in Pseudomonas species, and genetic analysis of P. extremaustralis showed that PHB genes are located in a genomic island [38,41], highlighting the importance of lateral gene transfer events for adaptability. The relevance of the metabolism of this polymer for cold adaptation was found by analyzing a PHB synthase mutant strain of P. extremaustralis $(p h b C)$. The mutant was unable to grow at $10^{\circ} \mathrm{C}$ and showed higher lipid peroxidation and a noticeable decrease in NADH/NAD ratio and NADPH content in comparison with the wild-type strain after a temperature downshift in which a rapid degradation of PHA was observed [39]. Protection conferred for PHA can lie in different non-excluding mechanisms. PHA metabolism is related to global stress responses, since an association between PHA degradation and the accumulation of the alarmone (p)ppGpp was found with a concomitant increase of the intracellular level of the master regulator RpoS [42,43]. In addition, a cryoprotective role was attributed to the PHB monomer, 3-hydroxybutyrate and it was observed that under freezing conditions PHB granules remain highly 
flexible, suggesting that they might protect bacterial cells against injury from intracellular and extracellular ice [44,45].

Regarding the PHA function in the cellular redox balance and the protection against oxidative stress derived from cold, some studies have reported that antioxidative enzymes (e.g., catalase, superoxide dismutase and glutathione peroxidase) are induced under cold conditions [46-48]. Some of these enzymes depend on nicotinamide dinucleotides as cofactors [49], giving an explanation regarding the PHA mechanism to cope with oxidative stress derived from cold exposure [32]. However, proteomic analysis performed in P. haloplanktis showed a repression of catalase, glutathione reductase and peroxiredoxin at low temperatures [15] and similar results were obtained in RNAseq experiments performed in P. extremaustralis, in which genes encoding the alkylhydroperoxidase, the glutathione peroxidase, the oxyR sensor and the superoxide dismutase were repressed at low temperatures in the early exponential growth phase [16]. Nevertheless, the adjustment of other pathways related to oxidative stress protection was found in these bacteria. The upregulation of algZ involved in alginate production and putrescine and spermidine accumulation genes was observed in concordance with the downregulation of iron acquisition, an important metabolic modification contributing to the alleviation of oxidative stress since iron is involved in the Fenton reaction $[13,14,17]$. In line with this, in Psychrobacter sp. PAMC 21119, putrescine synthesis was also found to be upregulated while heme protein synthesis was downregulated [20]. Putrescine and spermidine have been implicated in oxidative and cold stress responses [50,51].

In addition, screening for PHA producers was performed in different extreme cold environments. PHA producers belonging to Pseudomonas and Janthinobacterium genera, isolated from Antarctic soils, showed higher polymer accumulation between $5^{\circ} \mathrm{C}$ and $20^{\circ} \mathrm{C}$ in comparison with higher temperatures. The presence of highly unsaturated mclPHA in the isolate Pseudomonas sp. UMAB-40 was associated with its ability to survive in the cold [52]. PHA synthesis capability of bacterial isolates from Antarctic freshwater belonging to Alpha, Beta and Gammaproteobacteria was regarded as a common feature at pioneer sites [53]. Culture independent studies performed in extremely cold environments, such as the Baltic Sea and Greenland Sea ice, showed the presence of genes encoding PHA synthases in the bacterial community $[54,55]$, suggesting the relevance of this metabolism for the whole community.

All these reports constitute evidence that points out the synthesis and degradation of PHA as an important trait for thriving under cold conditions.

\section{Envelopes and Cold Adaptation}

The composition and structure of envelopes are recognized as important for cold adaptation as they constitute a dynamic interface between cell and environment, enabling them to cope with environmental challenges. Among the strategies used by cold-adapted microorganisms, a general well-known mechanism consists in the modification of cell membrane lipid composition, favoring shorter chains and decreasing lipid saturation [4] in order to maintain membrane fluidity while avoiding stiffness at low temperatures. Although the modifications of the internal membrane are well studied (Table 1), little is known about the changes that occur in other envelope components.

In Gram negative bacteria, the envelope consists of an inner and an outer membrane separated by the periplasmic space containing a thin peptidoglycan layer. The outer membrane is formed by phospholipids, proteins and lipopolysaccharide (LPS). LPS contains the lipid A, anchored to the membrane, an intermediate oligosaccharide component (core) and an external O-polysaccharide. In P. haloplanktis, the presence of a higher percentage of cell envelope genes in the genome has been suggested as a specialized adaptation to cope with cold [56]. Similar observations were reported for P. arcticus, in which genes involved in membrane lipid and cell wall synthesis were identified as relevant for growth under subzero temperatures [57]. Proteomic analysis of S. alaskensis showed that several proteins related to cell wall, membrane, exopolysaccharide biosynthesis and envelope biogenesis had a higher abundance at $10^{\circ} \mathrm{C}$ [18]. In the Antarctic bacterium Pseudomonas syringae Lz4w, it was observed that low temperatures caused changes in the composition and fluidity of LPS 
as higher polymyxin B sensitivity was detected along with an increased amount of hydroxy fatty acids [58]. In another Antarctic Pseudomonas - P. extremaustralis—-the relevance of the core integrity of the LPS to cope with cold was evidenced by analyzing a wapH mutant strain, encoding a core LPS glycosyltransferase [59]. The wapH strain was impaired to grow in the cold. The wapH deficiency provoked a strong aggregative phenotype and modifications of envelope nanomechanical properties, such as lower flexibility and higher turgor pressure, cell permeability and surface area to volume ratio $(\mathrm{S} / \mathrm{V})$. Changes in these characteristics were also observed when P. extremaustralis was grown at different temperatures. These results indicate that LPS appears as a novel essential feature for active growth under cold conditions [59].

In Gram positive bacteria where the envelope is composed of the cell wall and the inner membrane, the importance of these components has also been recognized. The increase in cell wall biosynthesis transcripts was observed in E. sibiricum at $-2.5^{\circ} \mathrm{C}$, suggesting that the thickening of the cell wall may protect the cell against disruption by ice formation and/or osmotic pressure, which can be generated at subzero temperatures [10]. Cell wall, membrane and envelope-component synthesis were also shown to be fundamental to supporting cold active growth in Planococcus halocryophilus Or1. This bacterium possesses an unusual cell envelope characterized by encrustations surrounding cells during subzero growth at $-15^{\circ} \mathrm{C}$ [13]. Transcriptomic analysis showed the relevance of genes encoding peptidoglycan synthetase, along with those involved in the synthesis of precursors [13]. Further microscopic characterization of the cell envelope showed increasing hydrophobicity and distinct extracellular encrustations of $20 \%$ calcium carbonate, $50 \%$ peptidoglycan and $29 \%$ choline closely associated with the cell wall. Along with this, genome analysis allowed the identification of several copies of genes encoding carbonic anhydrase, responsible for mineralization of calcium carbonate. The expression of a single copy of them, as well as genes related to peptidoglycan biosynthesis, was increased under low temperature conditions evidencing microbial-mediated calcium carbonate precipitation at subzero temperatures [60]. Another surprising feature of P. halocryophilus at sub-zero temperatures is that fatty-acid saturation increases with decreasing temperature [13]. It has been reported that $P$. halocryophilus employs an alternate mechanism for preserving membrane fluidity and that the fatty-acid desaturases are present but inactive at these temperatures [14].

Exopolysaccharides (EPS), which comprise a substantial component of the extracellular polymers surrounding bacterial cells, are also considered an important cellular function to cope with cold and ice $[40,61]$. Pseudoalteromonas sp., isolated from Arctic marine environments, produce a highly complex EPS with mannose as a main component, interestingly P. haloplanktis and other strains isolated from Antarctic environments also presented mannose as an important component of EPS [62-64]. These findings suggest that EPS production with specific characteristics is shared among cold-adapted bacteria. In addition, extracellular polymeric substances were related to the improvement of the freeze-thaw survival ratio in bacteria belonging to the Winogradskyella, Colwellia and Shewanella genera isolated from the Antarctic sponge [65], further indicating a cryoprotective role for these compounds.

Present evidence indicates the importance of the maintenance of membrane fluidity that appears as a common feature in cold-adapted bacteria but also highlights the relevance of several envelope components to cope with cold.

\section{Functional Attributes of Cold-Adapted Bacterial Communities}

In the next section, several cold bacterial community studies using global metagenome, metatranscriptome and metaproteome approaches are analyzed. The overall available information of these communities shows the constancy in general functional attributes involved in cold adaptation and the relevance of other metabolisms and features present in the complex microbial communities. Metagenome analysis of cyanobacterial mats from Arctic and Antarctic ice shelves showed that genes coding for functional responses to environmental stress such as exopolysaccharides, cold shock proteins and membrane modifications were found in all analyzed metagenomes [66]. The finding of a higher abundance of sequences (reads) matching the sigma B genes in the Antarctic mat was proposed as a 
feature reflecting more severe osmotic stress during freeze-up of the Antarctic ponds [66]. The results of six metagenomic datasets from different microbial mat communities of the perennially ice-covered Antarctic Lake Joyce were used to filter cold adaptation protein information, including antifreeze proteins, cold-shock DEAD-box protein A, cold-shock family of proteins (CSPs; including CspA, CspB, $\mathrm{CspC}, \mathrm{CspD}, \mathrm{CspE}$ and $\mathrm{CspG}$ ), fatty acid desaturase, ice nucleation protein and trehalose synthase [67]. The analysis showed that while the cold-shock family of proteins, cold-shock DEAD-box protein A, antifreeze proteins, fatty acid desaturase and trehalose synthase were present in all mat samples at different levels, the ice nucleation protein was only found at very low levels in some of the samples [67], probably reflecting the presence of generalized and particular mechanisms for cold adaptation in the bacterial communities. Interestingly, a metagenomic study of the biofilm and planktonic microbial communities of an acid mine drainage stream located below ground at a low-temperature $\left(6-10^{\circ} \mathrm{C}\right)$ in Kristineberg mine (Sweden) also showed functional characteristics previously reported as related to cold growth. These functional characteristics include cold-shock and anti-freeze proteins and several compatible solutes production pathways, besides the typical functions related to $\mathrm{pH}$ homeostasis and metal resistance expected to thrive in this acidic metal-containing ecosystem [68]. A recent metagenomic work analyzed the bacterial communities of Alaskan Pleistocene permafrost over geologic time by exploring a chronosequence from 19,000 to 33,000 years before the present day [69]. The results showed shifts consistent with long-term survival strategies involving scavenging detrital biomass, horizontal gene transfer, chemotaxis, dormancy, environmental sensing and stress response, thus associating the increase of abundance of many genes with age with microbial community adaptation to extreme cryogenic environment [69]. A comparative metaproteomic study of winter and summer bacterioplankton from Antarctic Peninsula coastal surface waters showed differences in each season [70]. While in the summer, autotrophic carbon assimilation appears to be driven by oxygenic photoautotrophy, consistent with high light availability and intensity, during the dark winter chemolithoautotrophic metabolism involving the 3-hydroxypropionate/4-hydroxybutyrate cycle and the reverse tricarboxylic acid cycle represented the main processes [70]. Metatranscriptome analysis of microbial communities in Alaskan permafrost soils showed the dominance of stress responses, survival strategies and maintenance processes under frozen conditions, while upon thawing, a rapid enzymatic response to decomposing soil organic matter was observed as well as transcripts related to acetogenesis and heterotrophic methanogenic pathways utilizing acetate, methanol and methylamine [71].

The understanding of microbial communities is complex, because many metabolic groups coexist in the environment and much remains to be discovered. However, several studies have highlighted the presence of features recognized as relevant to coping with cold, such as cold shock proteins, compatible solutes, exopolysaccharides and membrane modifications. In addition, it was shown that permafrost communities may use a highly diverse and complex set of biochemical processes involved in carbon processing, organic matter decomposition, methane generation and oxidation and nitrogen cycling [69]. These findings provide new insights into microbial communities and their functions in Arctic environments impacted by climate change [69].

\section{Conclusions}

The available information regarding cold-adapted bacteria demonstrated that metabolic traits related to energy generation are adjusted during cold growth (Figure 1). These involve the use of secondary pathways or the generation of intermediate compounds to bypass the ROS-generating pathways (Table 1). In addition, a wide set of compounds and mechanisms involved in stress resistance are displayed, along with modifications in envelope components that arise as important novel features for cold adaptation (Figure 1). Reports analyzing the functioning of the whole community have also demonstrated the presence of the classical features recognized as relevant for coping with cold, such as cold shock proteins, compatible solutes, exopolysaccharides and membrane modifications (Figure 1) but also showed the presence of a highly diverse set of metabolic features. 


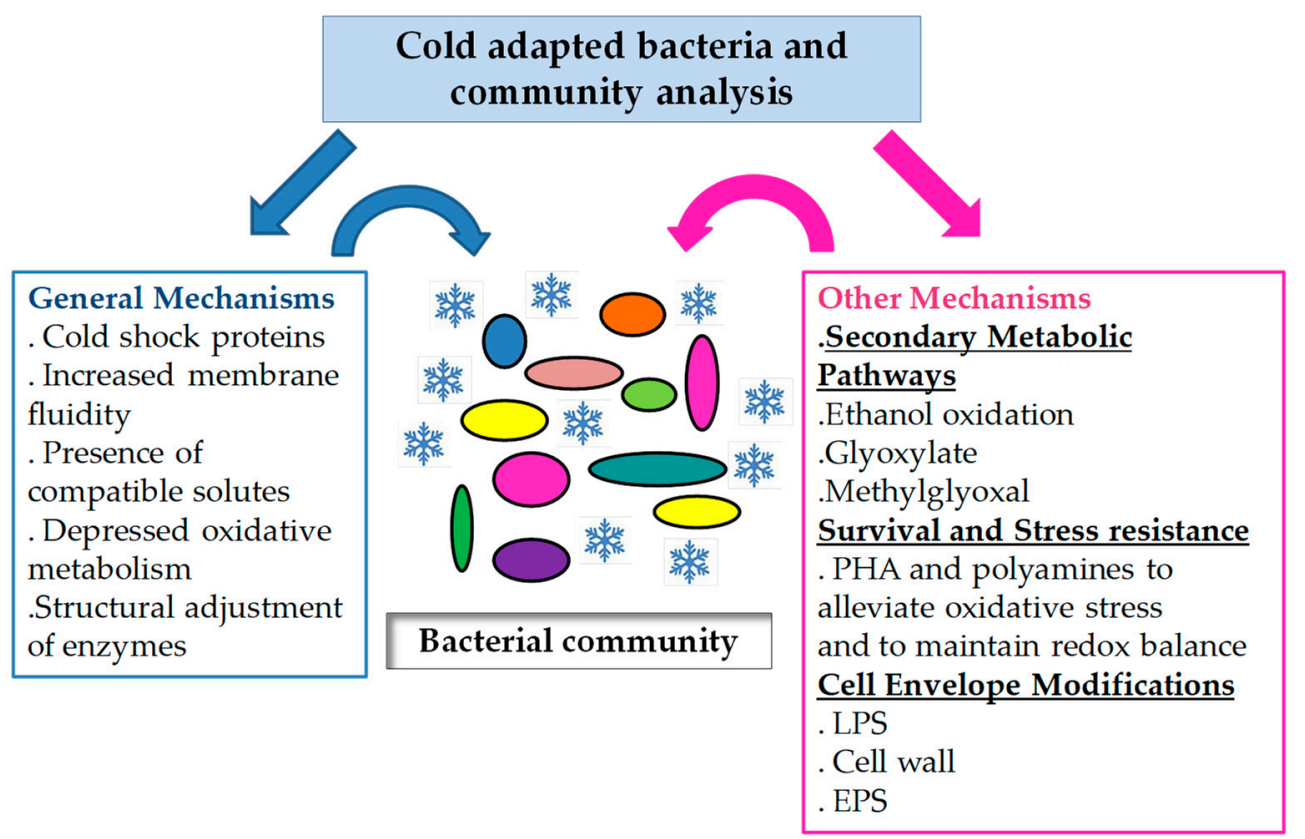

Figure 1. Mechanisms for cold adaptation. Available information regarding cold-adapted bacteria and microbial communities inhabiting cold environments shows that generalized and particular mechanisms could act in concert giving rise to cold adaptation profile of the entire community.

Acknowledgments: We thank Martiniano M. Ricardi for critical reading of the manuscript. This work was supported by grants from Universidad de Buenos Aires (UBACyT N ${ }^{\circ}$ 20020130100451BA) and Agencia Nacional de Promoción Científica (ANPCyT: PICT 2013, N 2259), Argentina. P.M.T. and N.I.L. are career investigators from Consejo Nacional de Investigaciones Científicas y Técnicas (CONICET, Argentina).

Author Contributions: P.M.T. and N.I.L. conceived, designed and wrote the paper.

Conflicts of Interest: The authors declare no conflict of interest.

\section{References}

1. Chattopadhyay, M.K.; Raghu, G.; Sharma, Y.V.R.K.; Biju, A.R.; Rajasekharan, M.V.; Shivaji, S. Increase in oxidative stress at low temperature in an Antarctic bacterium. Curr. Microbiol. 2011, 62, 544-546. [CrossRef] [PubMed]

2. Rodrigues, D.F.; Tiedje, J.M. Coping with our cold planet. Appl. Environ. Microbiol. 2008, 74, 1677-1686. [CrossRef] [PubMed]

3. Barria, C.; Malecki, M.; Arraiano, C.M. Bacterial adaptation to cold. Microbiology 2013, 159, $2437-2443$. [CrossRef] [PubMed]

4. De Maayer, P.; Anderson, D.; Cary, C.; Cowan, D.A. Some like it cold: Understanding the survival strategies of psychrophiles. EMBO Rep. 2014, 15, 508-517. [CrossRef] [PubMed]

5. Maccario, L.; Sanguino, L.; Vogel, T.M.; Larose, C. Snow and ice ecosystems: Not so extreme. Res. Microbiol. 2015, 166, 782-795. [CrossRef] [PubMed]

6. Cavicchioli, R. On the concept of a psychrophile. ISME J. 2016, 10, 793-795. [CrossRef] [PubMed]

7. Morita, R.Y. Psychrophilic bacteria. Bacteriol. Rev. 1975, 39, 144-167. [PubMed]

8. Atlas, R.M.; Bartha, R. Microbial Ecology: Fundamentals and Applications, 4th ed.; Benjamin/Cummings Science Publishers: Menlo Park, CA, USA, 1998; pp. 1-704.

9. Feller, G.; Gerday, C. Psychrophilic enzymes: Hot topics in cold adaptation. Nat. Rev. Microbiol. 2003, 1, 200-208. [CrossRef] [PubMed]

10. Rodrigues, D.F.; Ivanova, N.; He, Z.; Huebner, M.; Zhou, J.; Tiedje, J.M. Architecture of thermal adaptation in an Exiguobacterium sibiricum strain isolated from 3 million year old permafrost: A genome and transcriptome approach. BMC Genom. 2008, 9. [CrossRef] [PubMed] 
11. Aliyu, H.; De Maayer, P.; Cowan, D. The genome of the Antarctic polyextremophile Nesterenkonia sp. AN1 reveals adaptive strategies for survival under multiple stress conditions. FEMS Microbiol. Ecol. 2016, 92. [CrossRef] [PubMed]

12. Raymond-Bouchard, I.; Chourey, K.; Altshuler, I.; Iyer, R.; Hettich, R.L.; Whyte, L.G. Mechanisms of subzero growth in the cryophile Planococcus halocryophilus determined through proteomic analysis. Environ. Microbiol. 2017, 19, 4460-4479. [CrossRef] [PubMed]

13. Mykytczuk, N.C.S.; Foote, S.J.; Omelon, C.R.; Southam, G.; Greer, C.W.; Whyte, L.G. Bacterial growth at $-15{ }^{\circ} \mathrm{C}$; molecular insights from the permafrost bacterium Planococcus halocryophilus Or1. ISME J. 2013, 7, 1211-1226. [CrossRef] [PubMed]

14. Ronholm, J.; Raymond-Bouchard, I.; Creskey, M.; Cyr, T.; Cloutis, E.A.; Whyte, L.G. Characterizing the surface-exposed proteome of Planococcus halocryophilus during cryophilic growth. Extremophiles 2015, 19, 619-629. [CrossRef] [PubMed]

15. Piette, F.; D’Amico, S.; Mazzucchelli, G.; Danchin, A.; Leprince, P.; Feller, G. Life in the cold: A proteomic study of cold-repressed proteins in the antarctic bacterium Pseudoalteromonas haloplanktis TAC125. Appl. Environ. Microbiol. 2011, 77, 3881-3883. [CrossRef] [PubMed]

16. Tribelli, P.M.; Venero, E.C.S.; Ricardi, M.M.; Gómez-Lozano, M.; Iustman, L.J.R.; Molin, S.; López, N.I. Novel essential role of ethanol oxidation genes at low temperature revealed by transcriptome analysis in the antarctic bacterium Pseudomonas extremaustralis. PLoS ONE 2015, 10, e0145353. [CrossRef] [PubMed]

17. Ayala-Del-Río, H.; Chain, P.S.; Grzymski, J.J.; Ponder, M.A.; Ivanova, N.; Bergholz, P.W.; Di Bartolo, G.; Hauser, L.; Land, M.; Bakermans, C.; et al. The genome sequence of Psychrobacter arcticus 273-4, a psychroactive siberian permafrost bacterium, reveals mechanisms for adaptation to low-temperature growth. Appl. Environ. Microbiol. 2010, 76, 2304-2312. [CrossRef] [PubMed]

18. Ting, L.; Williams, T.J.; Cowley, M.J.; Lauro, F.M.; Guilhaus, M.; Raftery, M.J.; Cavicchioli, R. Cold adaptation in the marine bacterium, Sphingopyxis alaskensis, assessed using quantitative proteomics. Environ. Microbiol. 2010, 12, 2658-2676. [CrossRef] [PubMed]

19. Piette, F.; Leprince, P.; Feller, G. Is there a cold shock response in the Antarctic psychrophile Pseudoalteromonas haloplanktis? Extremophiles 2012, 16, 681-683. [CrossRef] [PubMed]

20. Koh, H.Y.; Park, H.; Lee, J.H.; Han, S.J.; Sohn, Y.C.; Lee, S.G. Proteomic and transcriptomic investigations on cold-responsive properties of the psychrophilic Antarctic bacterium Psychrobacter sp. PAMC 21119 at subzero temperatures. Environ. Microbiol. 2017, 19, 628-644. [CrossRef] [PubMed]

21. Fonseca, P.; Moreno, R.; Rojo, F. Growth of Pseudomonas putida at low temperature: Global transcriptomic and proteomic analyses. Environ. Microbiol. Rep. 2011, 3, 329-339. [CrossRef] [PubMed]

22. Textor, S.; Wendisch, V.F.; De Graaf, A.A.; Müller, U.; Linder, M.I.; Linder, D.; Buckel, W. Propionate oxidation in Escherichia coli: Evidence for operation of a methylcitrate cycle in bacteria. Arch. Microbiol. 1997, 168, 428-436. [CrossRef] [PubMed]

23. Horswill, A.R.; Escalante-Semerena, J.C. Salmonella typhimurium LT2 catabolizes propionate via the 2-methylcitric acid cycle. J. Bacteriol. 1999, 181, 5615-5623. [PubMed]

24. Regenhardt, D.; Heuer, H.; Heim, S.; Fernandez, D.U.; Strömpl, C.; Moore, E.R.B.; Timmis, K.N. Pedigree and taxonomic credentials of Pseudomonas putida strain KT2440. Environ. Microbiol. 2002, 4, 912-915. [CrossRef] [PubMed]

25. Reva, O.N.; Weinel, C.; Weinel, M.; Böhm, K.; Stjepandic, D.; Hoheisel, J.D.; Tümmler, B. Functional genomics of stress response in Pseudomonas putida KT2440. J. Bacteriol. 2006, 188, 4079-4092. [CrossRef] [PubMed]

26. Raiger Iustman, L.J.; Tribelli, P.M.; Ibarra, J.; Catone, M.V.; Solar Venero, E.C.; López, N.I. Genome sequence analysis of Pseudomonas extremaustralis provides new insights into environmental adaptability and extreme conditions resistance. Extremophiles 2015, 19, 207-220. [CrossRef] [PubMed]

27. Methe, B.A.; Nelson, K.E.; Deming, J.W.; Momen, B.; Melamud, E.; Zhang, X.; Moult, J.; Madupu, R.; Nelson, W.C.; Dodson, R.J.; et al. The psychrophilic lifestyle as revealed by the genome sequence of Colwellia psychrerythraea $34 \mathrm{H}$ through genomic and proteomic analyses. Proc. Natl. Acad. Sci. USA 2005, 102, 10913-10918. [CrossRef] [PubMed]

28. Collins, R.E.; Deming, J.W. An inter-order horizontal gene transfer event enables the catabolism of compatible solutes by Colwellia psychrerythraea 34H. Extremophiles 2013, 17, 601-610. [CrossRef] [PubMed] 
29. Mocali, S.; Chiellini, C.; Fabiani, A.; Decuzzi, S.; Pascale, D.; Parrilli, E.; Tutino, M.L.; Perrin, E.; Bosi, E.; Fondi, M.; et al. Ecology of cold environments: New insights of bacterial metabolic adaptation through an integrated genomic-phenomic approach. Sci. Rep. 2017, 7, 839. [CrossRef] [PubMed]

30. Nunn, B.L.; Slattery, K.V.; Cameron, K.A.; Timmins-Schiffman, E.; Junge, K. Proteomics of Colwellia psychrerythraea at subzero temperatures-A life with limited movement, flexible membranes and vital DNA repair. Environ. Microbiol. 2015, 17, 2319-2335. [CrossRef] [PubMed]

31. Ghobakhlou, A.F.; Johnston, A.; Harris, L.; Antoun, H.; Laberge, S. Microarray transcriptional profiling of Arctic Mesorhizobium strain N33 at low temperature provides insights into cold adaption strategies. BMC Genom. 2015, 16, 383. [CrossRef] [PubMed]

32. López, N.I.; Pettinari, M.J.; Nikel, P.I.; Méndez, B.S. Polyhydroxyalkanoates: Much more than biodegradable plastics. Adv. Appl. Microbiol. 2015, 93, 73-106. [PubMed]

33. Matin, A.; Veldhuis, C.; Stegeman, V.; Veenhuis, M. Selective advantage of a Spirillum sp. in a carbon-limited environment. Accumulation of poly-beta-hydroxybutyric acid and its role in starvation. J. Gen. Microbiol. 1979, 112, 349-355. [CrossRef] [PubMed]

34. López, N.I.; Floccari, M.E.; Steinbüchel, A.; García, A.F.; Méndez, B.S. Effect of poly(3-hydroxybutyrate) (PHB) content on the starvation-survival of bacteria in natural waters. FEMS Microbiol. Ecol. 1995, 16, 95-101. [CrossRef]

35. Handrick, R.; Reinhardt, S.; Jendrossek, D. Mobilization of poly(3-hydroxybutyrate) in Ralstonia eutropha. J. Bacteriol. 2000, 182, 5916-5918. [CrossRef] [PubMed]

36. Kadouri, D.; Jurkevitch, E.; Okon, Y. Involvement of the reserve material poly- $\beta$-hydroxybutyrate in Azospirillum brasilense stress endurance and root colonization. Appl. Environ. Microbiol. 2003, 69, 3244-3250. [CrossRef] [PubMed]

37. Mezzina, M.P.; Pettinari, M.J. Phasins, multifaceted polyhydroxyalkanoate granule-associated proteins. Appl. Environ. Microbiol. 2016, 82, 5060-5067. [CrossRef] [PubMed]

38. Catone, M.V.; Ruiz, J.A.; Castellanos, M.; Segura, D.; Espin, G.; López, N.I. High polyhydroxybutyrate production in Pseudomonas extremaustralis is associated with differential expression of horizontally acquired and core genome polyhydroxyalkanoate synthase genes. PLoS ONE 2014, 9, e98873. [CrossRef] [PubMed]

39. Ayub, N.D.; Tribelli, P.M.; López, N.I. Polyhydroxyalkanoates are essential for maintenance of redox state in the Antarctic bacterium Pseudomonas sp. 14-3 during low temperature adaptation. Extremophiles 2009, 13, 59-66. [CrossRef] [PubMed]

40. Tribelli, P.M.; López, N.I. Poly(3-hydroxybutyrate) influences biofilm formation and motility in the novel Antarctic species Pseudomonas extremaustralis under cold conditions. Extremophiles 2011, 15, 541. [CrossRef] [PubMed]

41. Ayub, N.D.; Pettinari, M.J.; Méndez, B.S.; López, N.I. The polyhydroxyalkanoate genes of a stress resistant Antarctic Pseudomonas are situated within a genomic island. Plasmid 2007, 58, 240-248. [CrossRef] [PubMed]

42. Ruiz, J.A.; López, N.I.; Fernández, R.O.; Méndez, B.S. Polyhydroxyalkanoate degradation is associated with nucleotide accumulation and enhances stress resistance and survival of Pseudomonas oleovorans in natural water microcosms. Appl. Environ. Microbiol. 2001, 67, 225-230. [CrossRef] [PubMed]

43. Ruiz, J.A.; López, N.I.; Méndez, B.S. rpoS gene expression in carbon-starved cultures of the polyhydroxyalkanoateaccumulating species Pseudomonas oleovorans. Curr. Microbiol. 2004, 48, 396-400. [CrossRef] [PubMed]

44. Obruca, S.; Sedlacek, P.; Krzyzanek, V.; Mravec, F.; Hrubanova, K.; Samek, O.; Kucera, D.; Benesova, P.; Marova, I. Accumulation of poly(3-hydroxybutyrate) helps bacterial cells to survive freezing. PLoS ONE 2016, 11, e0157778. [CrossRef] [PubMed]

45. Obruca, S.; Sedlacek, P.; Mravec, F.; Samek, O.; Marova, I. Evaluation of 3-hydroxybutyrate as an enzyme-protective agent against heating and oxidative damage and its potential role in stress response of poly(3-hydroxybutyrate) accumulating cells. Appl. Microbiol. Biotechnol. 2016, 100, 1365-1376. [CrossRef] [PubMed]

46. Smirnova, G.V.; Zakirova, O.N.; Oktyabrskii, O.N. The role of antioxidant systems in the cold stress response of Escherichia coli. Microbiology 2001, 70, 45-50. [CrossRef]

47. Zhang, L.; Onda, K.; Imai, R.; Fukuda, R.; Horiuchi, H.; Ohta, A. Growth temperature downshift induces antioxidant response in Saccharomyces cerevisiae. Biochem. Biophys. Res. Commun. 2003, 307, 308-314. [CrossRef] 
48. Margesin, R.; Miteva, V. Diversity and ecology of psychrophilic microorganisms. Res. Microbiol. 2011, 162, 346-361. [CrossRef] [PubMed]

49. Cabiscol, E.; Tamarit, J.; Ros, J. Oxidative stress in bacteria and protein damage by reactive oxygen species. Int. Microbiol. 2000, 3, 3-8. [CrossRef] [PubMed]

50. Tkachenko, A.G.; Pshenichnov, M.R.; Nesterova, L.Y. Putrescine as a factor protecting Escherichia coli against oxidative stress. Microbiology 2001, 70, 422-428. [CrossRef]

51. Zhu, X.; Li, Q.; Yin, C.; Fang, X.; Xu, X. Role of spermidine in overwintering of cyanobacteria. J. Bacteriol. 2015, 197, 2325-2334. [CrossRef] [PubMed]

52. Goh, Y.S.; Tan, I.K.P. Polyhydroxyalkanoate production by antarctic soil bacteria isolated from Casey Station and Signy Island. Microbiol. Res. 2012, 167, 211-219. [CrossRef] [PubMed]

53. Ciesielski, S.; Górniak, D.; Możejko, J.; Świątecki, A.; Grzesiak, J.; Zdanowski, M. The diversity of bacteria isolated from Antarctic freshwater reservoirs possessing the ability to produce polyhydroxyalkanoates. Curr. Microbiol. 2014, 69, 594-603. [CrossRef] [PubMed]

54. Luhtanen, A.M.; Eronen-Rasimus, E.; Kaartokallio, H.; Rintala, J.M.; Autio, R.; Roine, E. Isolation and characterization of phage-host systems from the Baltic Sea ice. Extremophiles 2014, 18, 121-130. [CrossRef] [PubMed]

55. Parnanen, K.; Karkman, A.; Virta, M.; Eronen-Rasimus, E.; Kaartokallio, H. Discovery of bacterial polyhydroxyalkanoate synthase (PhaC)-encoding genes from seasonal Baltic Sea ice and cold estuarine waters. Extremophiles 2015, 19, 197-206. [CrossRef] [PubMed]

56. Médigue, C.; Krin, E.; Pascal, G.; Barbe, V.; Bernsel, A.; Bertin, P.N.; Cheung, F.; Cruveiller, S.; D'Amico, S.; Duilio, A.; et al. Coping with cold: The genome of the versatile marine Antarctica bacterium Pseudoalteromonas haloplanktis TAC125. Genome Res. 2005, 15, 1325-1335. [CrossRef] [PubMed]

57. Bergholz, P.W.; Bakermans, C.; Tiedje, J.M. Psychrobacter arcticus 273-4 Uses resource efficiency and molecular motion adaptations for subzero temperature growth. J. Bacteriol. 2009, 191, 2340-2352. [CrossRef] [PubMed]

58. Kumar, G.S.; Jagannadham, M.V.; Ray, M.K. Low-temperature-induced changes in composition and fluidity of lipopolysaccharides in the antarctic psychrotrophic bacterium Pseudomonas syringae. J. Bacteriol. 2002, 184, 6746-6749. [CrossRef] [PubMed]

59. Benforte, F.C.; Colonnella, M.A.; Ricardi, M.M.; Venero, E.C.S.; Lizarraga, L.; López, N.I.; Tribelli, P.M. Novel role of the LPS core glycosyltransferase WapH for cold adaptation in the Antarctic bacterium Pseudomonas extremaustralis. PLoS ONE 2018, 13, e0192559. [CrossRef] [PubMed]

60. Mykytczuk, N.C.S.; Lawrence, J.R.; Omelon, C.R.; Southam, G.; Whyte, L.G. Microscopic characterization of the bacterial cell envelope of Planococcus halocryophilus Or1 during subzero growth at $-15{ }^{\circ} \mathrm{C}$. Polar Biol. 2016, 39, 701-712. [CrossRef]

61. Mancuso Nichols, C.A.; Garon, S.; Bowman, J.P.; Raguénès, G.; Guézennec, J. Production of exopolysaccharides by Antarctic marine bacterial isolates. J. Appl. Microbiol. 2004, 96, 1057-1066. [CrossRef] [PubMed]

62. Corsaro, M.M.; Lanzetta, R.; Parrilli, E.; Parrilli, M.; Tutino, M.L.; Ummarino, S. Influence of growth temperature on lipid and phosphate contents of surface polysaccharides from the antarctic bacterium Pseudoalteromonas haloplanktis TAC 125. J. Bacteriol. 2004, 186, 29-34. [CrossRef] [PubMed]

63. Nichols, C.M.; Lardière, S.G.; Bowman, J.P.; Nichols, P.D.; Gibson, J.A.E.; Guézennec, J. Chemical characterization of exopolysaccharides from Antarctic marine bacteria. Microb. Ecol. 2005, 49, 578-589. [CrossRef] [PubMed]

64. Caruso, C.; Rizzo, C.; Mangano, S.; Poli, A.; Di Donato, P.; Nicolaus, B.; Di Marco, G.; Michaud, L.; Lo Giudice, A. Extracellular polymeric substances with metal adsorption capacity produced by Pseudoalteromonas sp. MER144 from Antarctic seawater. Environ. Sci. Pollut. Res. Int. 2017, 25, 4667-4677. [CrossRef] [PubMed]

65. Caruso, C.; Rizzo, C.; Mangano, S.; Poli, A.; Di Donato, P.; Finore, I.; Nicolaus, B.; Di Marco, G.; Michaud, L.; Lo Giudice, A. Production and biotechnological potential of extracellular polymeric substances from sponge-sssociated antarctic bacteria. Appl. Environ. Microbiol. 2018, 84, e01624-17. [CrossRef] [PubMed]

66. Varin, T.; Lovejoy, C.; Jungblut, A.D.; Vincent, W.F.; Corbeil, J. Metagenomic analysis of stress genes in microbial mat communities from Antarctica and the high Arctic. Appl. Environ. Microbiol. 2012, 78, 549-559. [CrossRef] [PubMed] 
67. Koo, H.; Hakim, J.A.; Fisher, P.R.E.; Grueneberg, A.; Andersen, D.T.; Bej, A.K. Distribution of cold adaptation proteins in microbial mats in Lake Joyce, Antarctica: Analysis of metagenomic data by using two bioinformatics tools. J. Microbiol. Methods 2016, 120, 23-28. [CrossRef] [PubMed]

68. Liljeqvist, M.; Ossandon, F.J.; González, C.; Rajan, S.; Stell, A.; Valdes, J.; Holmes, D.S.; Dopson, M. Metagenomic analysis reveals adaptations to a cold-adapted lifestyle in a low-temperature acid mine drainage stream. FEMS Microbiol. Ecol. 2015, 91. [CrossRef] [PubMed]

69. MacKelprang, R.; Burkert, A.; Haw, M.; Mahendrarajah, T.; Conaway, C.H.; Douglas, T.A.; Waldrop, M.P. Microbial survival strategies in ancient permafrost: Insights from metagenomics. ISME J. 2017, 11, 2305-2318. [CrossRef] [PubMed]

70. Williams, T.J.; Long, E.; Evans, F.; Demaere, M.Z.; Lauro, F.M.; Raftery, M.J.; Ducklow, H.; Grzymski, J.J.; Murray, A.E.; Cavicchioli, R. A metaproteomic assessment of winter and summer bacterioplankton from Antarctic Peninsula coastal surface waters. ISME J. 2012, 6, 1883-1900. [CrossRef] [PubMed]

71. Coolen, M.J.L.; Orsi, W.D. The transcriptional response of microbial communities in thawing Alaskan permafrost soils. Front. Microbiol. 2015, 6, 197. [CrossRef] [PubMed]

(C) 2018 by the authors. Licensee MDPI, Basel, Switzerland. This article is an open access article distributed under the terms and conditions of the Creative Commons Attribution (CC BY) license (http:/ / creativecommons.org/licenses/by/4.0/). 